\title{
The role of yeast culture (Saccharomyces cerevisiae) on performance, egg yolk fatty acid composition, and fecal microflora of laying hens
}

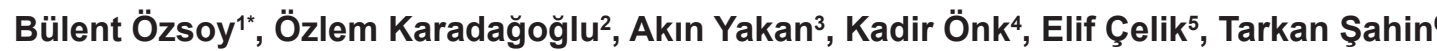

\footnotetext{
${ }^{1}$ Mustafa Kemal University, Veterinary Medicine Faculty, Department of Animal Nutrition and Nutritional Disease, Hatay, Turkey.

${ }^{2}$ Kafkas University, Kars Vocationel High School, Department of Agriculture and Animal Production, Kars, Turkey.

${ }^{3}$ Mustafa Kemal University, Veterinary Medicine Faculty, Department of Genetic, Hatay, Turkey.

${ }^{4}$ Kafkas University, Veterinary Medicine Faculty, Department of Animal Science, Kars, Turkey.

${ }^{5}$ Kafkas University, Veterinary Medicine Faculty, Department of Microbiology, Kars, Turkey.

${ }^{6}$ Kafkas University, Veterinary Medicine Faculty, Department of Animal Nutrition and Nutritional Disease, Kars, Turkey.
}

\begin{abstract}
This study investigated the effects of different levels $(0.05,0.1$, and $0.2 \%)$ of yeast culture supplementation on body weight, feed intake, feed conversion ratio, egg production, egg weight, egg quality traits, egg yolk fatty acid composition, and microbiological flora in feces. A total of 240 laying hens at 18-19 weeks of age were divided into four groups and fed a basal diet containing $2750 \mathrm{kcal} / \mathrm{kg}$ metabolizable energy and $16 \%$ crude protein for 16 weeks. The basal diet was supplemented with $0.05,0.1$, and $0.2 \%$ commercial yeast culture product obtained from Saccharomyces cerevisiae. The different levels of yeast culture supplementation to the diets did not statistically affect body weight change among the treatments. However, feed intake was lowest in the group fed $0.2 \%$ of yeast culture. The highest egg weights were obtained from the groups fed 0.1 and $0.2 \%$ yeast culture, when compared with control group. Regarding fatty acid composition, linolenic acid (C18:2 n6) was lowest in the group fed $0.2 \%$ yeast culture. However, yeast culture supplementation to the diet did not alter the microbial flora. Yeast culture (S. cerevisiae) supplementation to the diet of laying hens is beneficial for increasing feed intake and egg weight of laying hens without affecting the microbial flora in their digestive system.
\end{abstract}

Key Words: laying hen, fatty acid, microbiological flora, yeast culture

\section{Introduction}

Feed additives, which are defined as substances, have long been added to animal diets to increase the utilization of feeds as well as the quantity and quality of animal products. Yeast cultures are complex fermented products containing metabolic agents produced by yeast during fermentation. Live yeast cultures contain digestive enzymes such as amylase, maltase, sucrose, lactate dehydrogenase, proteinase, polypeptides, dipeptidase, deaminase, transaminase, lipase, phospholipase, phosphatase, and phytase and provide higher digestibility (Stanley et al., 1993). Saccharomyces cerevisiae, which produces these properties, has been proven to have beneficial effects on poultry production, e.g., in reproduction, growth rate, egg production, and feed efficiency (Dawson, 1993). In addition, supplementation of yeast, yeast extracts, and yeast cultures to feed has

Received: June 29, 2017

Accepted: December 5, 2017

*Corresponding author: bulent58@gmail.com

Copyright (C) 2018 Sociedade Brasileira de Zootecnia. This is an Open Access article distributed under the terms of the Creative Commons Attribution License (http://creativecommons.org/licenses/by/4.0/), which permits unrestricted use, distribution, and reproduction in any medium, provided the original work is properly cited. provided economic and environmental benefits in poultry diets for the past 40 years (Stone, 2007). Saccharomyces cerevisiae is known to increase the biological value of nitrogenous compounds in the digestive tract and to reduce stress-producing factors in animals. Yeast culture also helps digestion by increasing the availability of nutrients (Stanley et al., 1993).

The positive effects of supplementation of yeast culture, which might also be called probiotics on the performance values of animals, have been attributed to many factors including (but not limited to) microbial flora, dose added to the feed, environmental conditions, and physical condition of the animal (Ceylan and Çiftçi, 2003). It has been shown that probiotic microorganisms reach the villi of the intestinal lumen earlier than pathogenic bacteria, thus preventing these pathogens from becoming trapped in the digestive tract (Hassanein and Soliman, 2010).

In other words, probiotic microorganisms compete with pathogenic microorganisms for binding to receptors (competitor exclusion). The positive effect may also be due to the strengthening of the natural defense system and the biological regulation of intestinal microflora of the host, as well as to the direct effect of the probiotic on health or the 
nutritional form of the probiotic (Shareef and Al-Dabbagh, 2009; Hassanein and Soliman, 2010).

This study aimed to investigate the effects of the different levels $(0.05,0.1$, and $0.2 \%)$ of yeast culture supplementation on feed intake (FI), feed conversion ratio (FCR), egg production, egg quality traits, egg yolk fatty acid composition, and microbiological flora in the feces of laying hens.

\section{Material and Methods}

A total of 240 laying hens at 18-19 weeks of age were divided into four groups (control and three trial groups) and fed for 16 weeks. Each group comprised 10 sub-groups, with each sub-group having six animals. The animals were fed a basal diet containing $2750 \mathrm{kcal} / \mathrm{kg}$ metabolizable energy and $16 \%$ crude protein (Table 1 ). The yeast culture (S. cerevisiae) was added to the diet at different levels $(0.05,0.1$, and $0.2 \%$ body weight $-\mathrm{BW})$. The BW was determined at the beginning and at the end of the study. The daily egg production of the groups was measured. The FI and FCR of animals were recorded weekly (Table 2).

In the 4th, 8th, 12th, and 16th weeks of the study, the egg internal and external quality traits were determined in 10 randomly selected eggs from each group, and measurements were repeated four times. Eggs were weighed twice a week for two successive days, and average weights were recorded (Table 3).

Egg yolk oil extraction was conducted using nine egg samples from each group as reported by AOAC (2000). Afterwards, methyl esters were formed with boron trifluoride. The fatty acid methyl esters were condensed under nitrogen gas and then analyzed by gas

Table 1 - Composition and nutrient level of basal diet

\begin{tabular}{lc}
\hline Item & \\
\hline Ingredient $\left(\mathrm{g} \mathrm{kg}^{-1}\right)$ & 645 \\
Corn & 150 \\
Soybean meal & 78 \\
Sunflower seed meal & 30 \\
Meat and bone meal & 0.5 \\
DL-methionine & 82 \\
Limestone & 10 \\
Dicalcium phosphate & 2 \\
Salt & 2.5 \\
Vitamin and mineral premix ${ }^{1}$ & \\
Calculated nutrient level & 2753 \\
Metabolizable energy $\left(\mathrm{kcal} \mathrm{kg}^{-1}\right)$ & 160 \\
Crude protein $\left(\mathrm{g} \mathrm{kg}^{-1}\right)$ & 34.5 \\
Ca $\left(\mathrm{g} \mathrm{kg}^{-1}\right)$ & 6.2 \\
$\mathrm{P}\left(\mathrm{g} \mathrm{kg}^{-1}\right)$ & \\
\hline
\end{tabular}

${ }^{1}$ Provides per $\mathrm{kg}: 15,372.00 \mathrm{mg}$ vitamin A; $6.28 \mathrm{mg}$ vitamin E; $0.64 \mathrm{mg}$ vitamin $\mathrm{K} 3$; $27.36 \mathrm{mg} \mathrm{Mn} ; 89 \mathrm{mg} \mathrm{Fe} ; 25 \mathrm{mg} \mathrm{Zn} ; 8.76 \mathrm{mg} \mathrm{Cu} ; 0.03 \mathrm{mg} \mathrm{Co} ; 0.05 \mathrm{mg} \mathrm{I}$; $0.91 \mathrm{mg} \mathrm{Se}$. chromatography-mass spectroscopy (HP 6890/5972). The Agilent HP88 $100 \times 250 \times 250 \mu \mathrm{m}$ column was used in the analysis. The column starting temperature was $120^{\circ} \mathrm{C}$, the final temperature was $230{ }^{\circ} \mathrm{C}$, and the injector and detector temperature was $250^{\circ} \mathrm{C}$. The injection speed was set to 50:1. Helium was used as a carrier gas.

Fecal samples, which were collected from each group, were placed into sterile plastic tubes in the last week of the experiment. Stool samples were diluted as $10: 1$ in physiological saline (FTS) containing $0.9 \% \mathrm{NaCl}$. Subsequently, the samples were diluted in a ten-fold $(\log 10)$ dilution series by using six tubes. Inoculation began from the lowest dilution rate. Plate count agar was used for general live (total mesophilic aerobic microorganism), MacConkey agar for coliform bacteria, and Sabouraud dextrose agar for yeast. Plate count agar was incubated in aerobic conditions for $48 \mathrm{~h}$ at $30^{\circ} \mathrm{C}$, MacConkey agar was incubated for $24 \mathrm{~h}$ at $37^{\circ} \mathrm{C}$ for coliform bacteria count, and Sabouraud dextrose agar was incubated at $45{ }^{\circ} \mathrm{C}$ for 72 h (Arda, 1985; Arda et al., 1997). After incubation, the media were counted and the averages were taken. The mean numbers for all dilution steps were then determined, and microorganism counts were recorded for each sample according to these results.

One-way ANOVA was used to determine the significance of the differences between the statistical calculations and mean values of the groups. The Duncan test was employed to determine the significance among the groups (Dawson and Trapp, 2001).

\section{Results}

During the experimental period, there was no side effect on the health of animals due to supplementation of yeast culture at the test concentrations added to the feed. The different levels of yeast culture supplementation to diets did not affect BW. The lowest average FI (101.96 $\mathrm{g} /$ day) was obtained from the group fed $0.2 \%$ yeast culture supplementation, when compared with control group (106.43 g/day) (Table 2).

The highest egg production was obtained from the groups fed 0.2 (91.54\%) and $0.1 \%$ supplemention (91.93\%), while control group had an average egg production of $90.30 \%(\mathrm{P}>0.05)$.

Yolk diameter was lowest in the group fed $0.1 \%$ supplementation, followed by the $0.05 \%$ supplementation, control, and $0.2 \%$ supplementation, in that order. In comparison with the control and $0.05 \%$ supplementation groups, the highest Haugh units were obtained from the $0.2 \%$ and $0.1 \%$-supplementation groups, respectively (Table 4 ). 
In terms of fatty acid composition (Table 5), hexadecanoic (C16:0) and oleic acids (C18:1) were the main fatty acids in the egg yolk. Myristoleic (C14:1) and hexadecanoic acid (C16:0) values were higher in the 0.1 and $0.2 \%$ yeast culture-supplementaation groups, when compared with control group ( $\mathrm{P}>0.05)$. Polyunsaturated fatty acids (PUFA) values were numerically lower in the $0.2 \%$ yeast culture-supplementation group than in the other groups. However, PUFA:saturated fatty acids (SFA) and C18:2 n6 values were significantly different between the control and experimental groups $(\mathrm{P}<0.05)$.

The microbiological analysis of feces (Table 6 ) revealed that dietary supplementation of yeast culture did not influence the total bacterial number $(\mathrm{P}=0.50)$. The number of coliform bacteria was lowest $(1.35 \pm 0.59 \log 10 \mathrm{cfu} / \mathrm{g})$ in the $0.2 \%$ yeast culture-supplementation group $(\mathrm{P}=0.89)$.

Table 2 - Effects of yeast culture on laying hen performance

\begin{tabular}{|c|c|c|c|c|c|}
\hline & Control group & Experimental group 1 & Experimental group 2 & Experimental group 3 & P-value \\
\hline Initial body weight (g) & $1757 \pm 19.12$ & $1740 \pm 18.20$ & $1758 \pm 14.34$ & $1761 \pm 8.53$ & 0.812 \\
\hline Final body weight (g) & $1720 \pm 17.86$ & $1707 \pm 16.90$ & $1750 \pm 19.36$ & $1756 \pm 21.23$ & 0.211 \\
\hline Egg production/hen/day (\%) & $90.30 \pm 0.60$ & $90.93 \pm 0.52$ & $91.54 \pm 0.53$ & $91.35 \pm 0.43$ & 0.35 \\
\hline Feed intake (g/day per hen) & $106.43 \pm 1.17 \mathrm{a}$ & $105.23 \pm 0.85 \mathrm{a}$ & $104.82 \pm 1.05 \mathrm{ab}$ & $101.96 \pm 1.15 b$ & 0.03 \\
\hline Feed conversion ratio ( $\mathrm{g}$ feed/g egg) & $2.03 \pm 0.03$ & $1.99 \pm 0.03$ & $1.97 \pm 0.02$ & $1.94 \pm 0.07$ & 0.07 \\
\hline
\end{tabular}

Control group: basal diet; Experiemental group 1: basal diet $+0.05 \%$ yeast culture; Experimental group 2: basal diet $+0.1 \%$ yeast culture; Experimental group 3: basal diet $+0.2 \%$ yeast culture.

$\mathrm{a}-\mathrm{b}$ - Means within a row with different letters are different at $\mathrm{P}<0.05$.

Table 3 - Weekly egg weights $(\mathrm{g})$

\begin{tabular}{|c|c|c|c|c|c|}
\hline Week & Control group & Experimental group 1 & Experimental group 2 & Experimental group 3 & P-value \\
\hline $1-2$ & $\begin{array}{l}56.97 \pm 0.51 \\
\mathrm{n}=55\end{array}$ & $\begin{array}{c}56.83 \pm 0.44 \\
\mathrm{n}=55\end{array}$ & $\begin{array}{c}57.38 \pm 0.51 \\
\mathrm{n}=53\end{array}$ & $\begin{array}{c}56.34 \pm 0.53 \\
\mathrm{n}=51\end{array}$ & 0.54 \\
\hline $3-4$ & $\begin{array}{c}57.70 \pm 0.46 \\
\mathrm{n}=55\end{array}$ & $\begin{array}{c}57.69 \pm 0.46 \\
\mathrm{n}=58\end{array}$ & $\begin{array}{c}58.49 \pm 0.54 \\
\mathrm{n}=53\end{array}$ & $\begin{array}{c}58.58 \pm 0.62 \\
\mathrm{n}=53\end{array}$ & 0.44 \\
\hline $5-6$ & $\begin{array}{c}58.78 \pm 0.51 \\
\mathrm{n}=58\end{array}$ & $\begin{array}{c}58.52 \pm 0.44 \\
\mathrm{n}=60\end{array}$ & $\begin{array}{c}58.79 \pm 0.56 \\
\mathrm{n}=57\end{array}$ & $\begin{array}{c}59.17 \pm 0.53 \\
\mathrm{n}=50\end{array}$ & 0.85 \\
\hline $7-8$ & $\begin{array}{c}58.37 \pm 0.59 \\
\mathrm{n}=56\end{array}$ & $\begin{array}{c}57.86 \pm 0.51 \\
\mathrm{n}=58\end{array}$ & $\begin{array}{c}60.19 \pm 0.65 \mathrm{a} \\
\mathrm{n}=58\end{array}$ & $\begin{array}{c}60.36 \pm 0.54 \mathrm{a} \\
\mathrm{n}=57\end{array}$ & 0.003 \\
\hline $9-10$ & $\begin{array}{c}57.67 \pm 0.71 b \\
\mathrm{n}=51\end{array}$ & $\begin{array}{c}58.28 \pm 0.64 \mathrm{ab} \\
\mathrm{n}=53\end{array}$ & $\begin{array}{c}58.55 \pm 0.54 \mathrm{ab} \\
\mathrm{n}=56\end{array}$ & $\begin{array}{c}59.97 \pm 0.55 \mathrm{a} \\
\mathrm{n}=58\end{array}$ & 0.052 \\
\hline $11-12$ & $\begin{array}{c}57.97 \pm 0.62 \mathrm{~b} \\
\mathrm{n}=53\end{array}$ & $\begin{array}{c}58.77 \pm 0.57 \mathrm{ab} \\
\mathrm{n}=52\end{array}$ & $\begin{array}{c}59.80 \pm 0.65 \mathrm{a} \\
\mathrm{n}=56\end{array}$ & $\begin{array}{c}60.44 \pm 0.53 \mathrm{a} \\
\mathrm{n}=56\end{array}$ & 0.019 \\
\hline $13-14$ & $\begin{array}{c}58.84 \pm 0.61 \mathrm{~b} \\
\mathrm{n}=54\end{array}$ & $\begin{array}{c}59.89 \pm 0.57 \mathrm{ab} \\
\mathrm{n}=55\end{array}$ & $\begin{array}{c}60.96 \pm 0.53 \mathrm{a} \\
\mathrm{n}=56\end{array}$ & $\begin{array}{c}60.51 \pm 0.46 \mathrm{a} \\
\mathrm{n}=56\end{array}$ & 0.041 \\
\hline
\end{tabular}

Control group: basal diet; Experiemental group 1: basal diet $+0.05 \%$ yeast culture; Experimental group 2: basal diet $+0.1 \%$ yeast culture; Experimental group 3: basal diet $+0.2 \%$ yeast culture.

$\mathrm{a}-\mathrm{b}$ - Means within a row with different letters are different at $\mathrm{P}<0.05$.

Table 4 - Effects of yeast culture on egg quality traits of laying hens

\begin{tabular}{|c|c|c|c|c|c|}
\hline & Control group & Experimental group 1 & Experimental group 2 & Experimental group 3 & P-value \\
\hline Egg weight (g) & $60.07 \pm 0.69$ & $58.85 \pm 0.66$ & $59.66 \pm 0.73$ & $59.78 \pm 0.63$ & 0.62 \\
\hline Shape index (\%) & $78.46 \pm 0.58$ & $77.28 \pm 0.43$ & $77.81 \pm 0.36$ & $78.02 \pm 0.59$ & 0.42 \\
\hline Shell weight (g) & $5.94 \pm 0.09$ & $5.81 \pm 0.13$ & $6.05 \pm 0.11$ & $6.08 \pm 0.09$ & 0.62 \\
\hline Albumen weight (g) & $39.72 \pm 0.62$ & $38.79 \pm 0.61$ & $39.18 \pm 0.67$ & $37.62 \pm 1.12$ & 0.29 \\
\hline Yolk weight $(\mathrm{g})$ & $14.41 \pm 0.17$ & $14.25 \pm 0.24$ & $14.44 \pm 0.21$ & $16.08 \pm 1.04$ & 0.07 \\
\hline Shell weight percentage (\%) & $9.90 \pm 0.13$ & $9.87 \pm 0.19$ & $10.14 \pm 0.16$ & $10.19 \pm 0.18$ & 0.38 \\
\hline Albumen weight percentage (\%) & $66.04 \pm 0.36$ & $65.85 \pm 0.49$ & $65.58 \pm 0.45$ & $62.91 \pm 1.69$ & 0.06 \\
\hline Yolk weight percentage $(\%)$ & $24.06 \pm 0.35$ & $24.28 \pm 0.44$ & $24.28 \pm 0.41$ & $26.90 \pm 1.67$ & 0.08 \\
\hline Yolk diameter (mm) & $39.23 \pm 0.31 \mathrm{ab}$ & $38.86 \pm 0.43 \mathrm{ab}$ & $38.08 \pm 0.41 b$ & $40.01 \pm 0.43 \mathrm{a}$ & 0.01 \\
\hline Yolk height (mm) & $21.49 \pm 0.28$ & $21.31 \pm 0.28$ & $21.25 \pm 0.26$ & $21.48 \pm 0.35$ & 0.92 \\
\hline Haugh unit & $79.86 \pm 0.30 \mathrm{~b}$ & $79.71 \pm 0.31 \mathrm{~b}$ & $80.49 \pm 0.37 \mathrm{ab}$ & $81.18 \pm 0.29 \mathrm{a}$ & 0.005 \\
\hline
\end{tabular}

Control group: basal diet; Experiemental group 1: basal diet $+0.05 \%$ yeast culture; Experimental group 2: basal diet $+0.1 \%$ yeast culture; Experimental group 3: basal diet $+0.2 \%$ yeast culture.

$\mathrm{a}-\mathrm{b}$ - Means within a row with different letters are different at $\mathrm{P}<0.05$. 
Table 5 - Effects of dietary supplementation of yeast culture on yolk fatty acids (\% of total methyl esters of fatty acids) of laying hens

\begin{tabular}{|c|c|c|c|c|c|}
\hline Fatty acid (\%) & Control group & Experimental group 1 & Experimental group 2 & Experimental group 3 & P-value \\
\hline C14:0 & $0.31 \pm 0.015$ & $0.31 \pm 0.016$ & $0.32 \pm 0.022$ & $0.30 \pm 0.020$ & 0.96 \\
\hline C14:1 & $0.014 \pm 0.004$ & $0.015 \pm 0.005$ & $0.023 \pm 0.005$ & $0.029 \pm 0.002$ & 0.09 \\
\hline$C: 16: 0$ & $23.96 \pm 0.44$ & $24.14 \pm 0.35$ & $24.07 \pm 0.34$ & $24.79 \pm 0.32$ & 0.41 \\
\hline C17:0 & $0.18 \pm 0.04$ & $0.20 \pm 0.015$ & $0.17 \pm 0.018$ & $0.26 \pm 0.062$ & 0.41 \\
\hline $\mathrm{C} 17: 1$ & $0.22 \pm 0.046$ & $0.15 \pm 0.018$ & $0.13 \pm 0.008$ & $0.18 \pm 0.030$ & 0.19 \\
\hline C18:0 & $8.87 \pm 0.23$ & $8.24 \pm 0.23$ & $8.30 \pm 0.20$ & $8.47 \pm 0.16$ & 0.15 \\
\hline $\mathrm{C} 18: 3 \mathrm{n} 6$ & $0.51 \pm 0.044$ & $0.43 \pm 0.043$ & $0.48 \pm 0.039$ & $0.45 \pm 0.028$ & 0.56 \\
\hline $\mathrm{C} 18: 3 \mathrm{n} 3$ & $0.88 \pm 0.040$ & $0.97 \pm 0.035$ & $0.94 \pm 0.048$ & $0.84 \pm 0.058$ & 0.23 \\
\hline C20:0 & $0.075 \pm 0.017$ & $0.061 \pm 0.006$ & $0.091 \pm 0.019$ & $0.12 \pm 0.025$ & 0.18 \\
\hline C20:1 & $0.34 \pm 0.045$ & $0.27 \pm 0.016$ & $0.26 \pm 0.019$ & $0.29 \pm 0.04$ & 0.3 \\
\hline $\mathrm{C} 20: 2 \mathrm{n} 6$ & $0.21 \pm 0.014$ & $0.25 \pm 0.024$ & $0.21 \pm 0.021$ & $0.21 \pm 0.030$ & 0.45 \\
\hline $\mathrm{C} 20: 3 \mathrm{n} 3$ & $0.19 \pm 0.018$ & $0.19 \pm 0.011$ & $0.17 \pm 0.011$ & $0.19 \pm 0.01$ & 0.77 \\
\hline MUFA & $44.61 \pm 0.64$ & $44.22 \pm 0.46$ & $44.56 \pm 0.66$ & $45.73 \pm 0.89$ & 0.44 \\
\hline PUFA & $21.86 \pm 0.66$ & $22.67 \pm 0.49$ & $22.32 \pm 0.48$ & $20.23 \pm 0.87$ & 0.06 \\
\hline UFA & $66.46 \pm 0.39$ & $66.89 \pm 0.39$ & $66.88 \pm 0.40$ & $65.96 \pm 0.27$ & 0.25 \\
\hline PUFA:SFA & $0.65 \pm 0.02 \mathrm{ab}$ & $0.69 \pm 0.02 \mathrm{a}$ & $0.67 \pm 0.02 \mathrm{a}$ & $0.59 \pm 0.03 b$ & 0.03 \\
\hline n6 & $20.24 \pm 0.59$ & $21.06 \pm 0.43$ & $20.74 \pm 0.43$ & $18.73 \pm 0.81$ & 0.07 \\
\hline n3 & $1.61 \pm 0.08$ & $1.61 \pm 0.07$ & $1.59 \pm 0.06$ & $1.50 \pm 0.06$ & 0.58 \\
\hline n6:n3 & $12.65 \pm 0.37$ & $13.16 \pm 0.47$ & $13.14 \pm 0.38$ & $12.50 \pm 0.17$ & 0.47 \\
\hline Nutritive value $^{1}$ & $2.09 \pm 0.06$ & $2.03 \pm 0.04$ & $2.05 \pm 0.04$ & $20.04 \pm 0.05$ & 0.83 \\
\hline Atherogenic index ${ }^{2}$ & $0.15 \pm 0.005$ & $0.14 \pm 0.003$ & $0.14 \pm 0.004$ & $0.15 \pm 0.003$ & 0.23 \\
\hline Thrombogenic index ${ }^{3}$ & $0.57 \pm 0.01$ & $0.57 \pm 0.009$ & $0.56 \pm 0.01$ & $0.58 \pm 0.01$ & 0.50 \\
\hline
\end{tabular}

Control group: basal diet; Experiemental group 1: basal diet $+0.05 \%$ yeast culture; Experimental group 2: basal diet $+0.1 \%$ yeast culture; Experimental group 3: basal diet $+0.2 \%$ yeast culture.

MUFA - monounsaturated fatty acids; PUFA - polyunsaturated fatty acids; UFA - unsaturated fatty acids; SFA - saturated fatty acids.

${ }^{1}(\mathrm{C} 18: 0+\mathrm{C} 18: 1) / \mathrm{C} 16: 0$.

$\left.{ }^{2}(4 * \mathrm{C} 14: 0)+\mathrm{C} 18: 0\right) / \mathrm{UFA}$.

${ }^{3}(\mathrm{C} 14: 0+\mathrm{C} 16: 0+\mathrm{C} 18: 0) /(0.5 * \mathrm{C} 18: 1)+(0.5 * \mathrm{MUFA})+(0.5 * \mathrm{n} 6)+(3 * \mathrm{n} 3)+(\mathrm{n} 3 / \mathrm{n} 6)$.

$\mathrm{a}-\mathrm{b}$ - Means within a row with different letters are different at $\mathrm{P}<0.05$.

Table 6 - Effects of dietary supplementation of yeast culture on fecal microflora $(\log 10 \mathrm{cfu} / \mathrm{g})$ of laying hens

\begin{tabular}{lccccc}
\hline & Control group & Experimental group 1 & Experimental group 2 & Experimental group 3 & P-value \\
\hline Total bacteria & $6.32 \pm 0.57$ & $6.13 \pm 0.99$ & $4.85 \pm 0.99$ & $4.78 \pm 0.97$ & 0.50 \\
Coliform bacteria & $1.71 \pm 0.58$ & $1.79 \pm 0.29$ & $1.80 \pm 0.39$ & $1.35 \pm 0.59$ & 0.89 \\
Yeast & $0.15 \pm 0.043$ & $0.36 \pm 0.15$ & $0.23 \pm 0.09$ & $0.29 \pm 0.05$ & 0.46 \\
\hline
\end{tabular}

Control group: basal diet; Experiemental group 1: basal diet $+0.05 \%$ yeast culture; Experimental group 2: basal diet $+0.1 \%$ yeast culture; Experimental group 3: basal diet $+0.2 \%$ yeast culture.

Non-significant differences $\mathrm{P}>0.05$.

\section{Discussion}

Studies on laying hens reported that addition of yeast culture or yeast metabolites did not affect BW (Yousefi and Karkoodi, 2007; Yalçın et al., 2012; Yalçın et al., 2014; Hassanein and Soliman, 2010). Similarly, our results also did not show any difference in the BW of laying hens. On the other hand, some studies indicated that yeast culture supplementation to broiler diets positively affected their BW (Shareef and Al-Dabbagh, 2009; Fasina and Thanissery, 2011; Fathi et al., 2012), which could be attributed to the strains of yeast and animal species, among other factors.
Although yeast culture supplementation had no statistical effect on egg production, a numerical increase was observed. Similar results were recorded for yeast or yeast metabolite supplementation to laying hen diets in many studies (Ayanvale et al., 2006; Asli et al., 2007; Yousefi and Karkoodi, 2007; Yalçin et al., 2008; Yalçın et al., 2012; Gül et al., 2013; Sacakli et al., 2013). On the other hand, Hassanein and Soliman (2010) observed an increase in egg production in laying hens by using yeast culture supplementation at much higher concentrations $(0.4,0.8$, 1.2 , and $1.6 \%$ ).

The different levels of yeast culture supplementation to diets significantly affected FI $(\mathrm{P}<0.05)$. Consistent with our 
findings, yeast culture supplementation positively affected FCR of broilers (Onifade and Babatunde 1996; Miazzo et al., 2005; Shareef and Al-Dabbagh, 2009) and laying hens (El-Ella et al., 1996; Katoch et al., 2003; Yalçın et al., 2012; Gül et al., 2013; Yalçın et al., 2015). Conversely, FI and FCR was not improved by yeast culture supplementation in laying hens (Nursoy et al., 2004; Asli et al., 2007; Yousefi and Karkoodi, 2007; Hassanein and Soliman, 2010; Sacakli et al., 2013), in laying quail (Önol et al., 2003), and in broiler turkeys (Özsoy and Yalçın, 2011).

The highest egg weight was observed in hens fed 0.1 and $0.2 \%$ yeast culture during the experimental period, and this difference was statistically significant $(\mathrm{P}<0.05)$. Our findings corroborate previous studies (Ayanvale et al., 2006; Yalçin et al., 2008; Yalçın et al., 2015; Zhong et al., 2016), but disagree with others (Nursoy et al., 2004; Asli et al., 2007; Hassanein and Soliman, 2010; Gül et al., 2013; Sacakli et al., 2013).

No statistical difference was observed for shape index, shell weight, albumen weight, or yolk height. These results are consistent with those of other studies (Asli et al., 2007; Hassanein and Soliman, 2010; Yalçın et al., 2012; Yalçın et al., 2014; Yalçın et al., 2015). Yolk weight $(\mathrm{P}<0.07)$, yolk weight percentage $(\mathrm{P}<0.08)$, and yolk diameter $(\mathrm{P}<0.01)$ were the highest in the group fed $0.2 \%$ yeast culture supplementation. The lowest albumen weight percentage was also found in the third trial group $(\mathrm{P}<0.06)$. Haugh unit was calculated as $79.86,79.71,80.49$, and 81.18 in the control and the three trial groups, respectively. The best Haugh unit was found in the third trial group $(\mathrm{P}<0.005)$. Similarly, previous studies (Ayanwale et al., 2006; Yousefi and Karkoodi, 2007; Asli et al., 2007; Zhong et al., 2016) reported that egg yolk weight was increased by the supplementation of yeast culture.

At the end of the experiment, egg yolk fatty acids C14-C24 were determined. The C18:2 n6 values were statistically different between the control and experimental groups $(\mathrm{P}<0.05)$. In addition, PUFA $(\mathrm{P}=0.06)$, PUFA/SFA $(\mathrm{P}<0.03)$, and $\mathrm{n} 6(\mathrm{P}=0.06)$ values were different between control and experimental groups. Yalçın et al. (2010) similarly reported that yeast autolysate supplementation decreased monounsaturated fatty acids (MUFA) and C18:1, but increased C14:0, C14:1, C20:0, C20:3n-3, and $C 20: 5 n-3$. Yalçın et al. (2012) also reported that only C18:1 and MUFA levels increased, and the other fatty acid parameters were not affected by yeast culture supplementation.

The positive effects of yeast culture supplementation on the natural defense system of the host animal and on the biological regulation of its intestinal microflora and the direct effect of the probiotic on health or the nutritional form of the probiotic have been previously reported (Shareef and Al-Dabbagh, 2009; Hassanein and Soliman, 2010). In the current study, total microbial counts, coliform bacteria, and yeast values were not altered in stool samples during the last week of the study. The lowest coliform bacteria value was found in the group fed $0.2 \%$ yeast culture supplementation. Fecal yeast count was higher in the yeast culture groups than in the control group. Gül et al. (2013) reported that the number of total bacteria was decreased, but the number of total yeast was increased in the intestine by yeast supplementation to laying hen diets. Another study (Hassanein and Soliman, 2010) reported that different levels $(0.4,0.8,1.2$, and $1.6 \%)$ of yeast supplementation to laying hen diets significantly reduced the number of total bacteria, especially in the $1.6 \%$ supplementation group. However, Wang et al. (2015) found that yeast supplementation increased the total number of bacteria in the intestine of laying hens.

\section{Conclusions}

Yeast culture supplementation, as a probiotic to laying hen diets, does not cause any health problems. It is thus suggested that the different levels of yeast supplementation (S. cerevisiae) in laying hen diets could increase the productivity of laying hens in terms of feed intake, egg weight, and egg Haugh unit.

\section{Acknowledgments}

The present study was supported by the Scientific Research Project Unit of Kafkas University, Turkey (Project Number: BAP 2016 TS 19).

\section{References}

AOAC - Association of Official Analytical Chemistry. 2000. Official methods of analysis. 17th ed. AOAC International, Arlington, VA.

Arda, M. 1985. Bakterilerin idendifikasyonları. p.266-271. In: Genel mikrobiyoloji. 3rd ed. Arda, M., ed. Ankara Üniversitesi Veteriner Fakültesi Dergisi, Ankara.

Arda, M.; Minbay, A.; Leloğlu, N.; Aydın, N.; Kahraman, M.; Akay, Ö.; Ilgaz. A; İzgür, M. and Diker, K. S. 1997. Fakültatif anaerobik gram negatif çomaklar. p.45-49. In: Özel mikrobiyoloji. 4th ed. Arda, M., ed. Medisan Yayınları, Ankara.

Asli, M. M.; Hosseini, S. A.; Lotfollahian, H. and Shariatmadari, F. 2007. Effect of probiotics, yeast, vitamin $\mathrm{E}$ and vitamin $\mathrm{C}$ supplements on performance and immune response of laying hen during high environmental temperature. International Journal of Poultry Science 6(12):895-900.

Ayanwale, B. A.; Kpe, M. and Ayanwale, V. A. 2006. The effect of supplementing Saccharomyces cerevisiae in the diets on egg 
laying and egg quality characteristics of pullets. International Journal of Poultry Science 5(8):759-763.

Ceylan, N. and Çiftçi, İ. 2003. Büyütme faktörü antibiyotiklere alternatif yem katkılarının etlik piliçlerde besi performansı ve bağırsak mikroflorası üzerine etkileri. Turk Journal Veterinary Animal Science 27:727-733.

Dawson, B. and Trapp, R. G. 2001. Basic and clinical biostatistics. 3rd ed. Lange Medical Books/McGraw-Hill Medical Publishing Division, New York.

Dawson, K. A. 1993. Current and future role of yeast culture in animal production: A review of research over the last seven years. p.169-171. In: Biotechnology in the feed industry. Proceedings of the 9th Annual Symposium. Alltech Technical Publications, Nicholasville, KY.

El-Ella, M. A. A.; Attiae, M. Y.; El-Nagmy, K. Y. and Radwan, M. A. H. 1996. The productive performance of layings fed diets supplemented with some commercial feed additives. Egyptian Journal Animal Production Suppl Issue. NoV. 33:423-431.

Fasina, Y. O. and Thanissery, R. R. 2011. Comparative efficacy of a yeast product and bacitracin methylene disalicylate in enhancing early growth and intestinal maturation in broiler chicks from breeder hens of different ages. Poultry Science 90(5):1067-1073.

Fathi, M. M.; Al-Mansour. S.; Al-Homidan. A.; Al-Khalaf, A. and Al-Damegh, M. 2012. Effect of yeast culture supplementation on carcass yield and humoral immune response of broiler chicks. Veterinary World 5:651-657.

Gül, M.; Yörük, M. A.; Sağlam, Y. S. and Aksu, T. 2013. Yumurta tavuğu rasyonlarına maya (Saccharomyces cerevisiae) ve Enterococcus faecium katkılarının performans, yumurta kalite kriterleri ve barsak mikroflorası üzerine etkileri. Atatürk Üniversitesi Veteriner Bilimleri Dergisi 8(2):137-144.

Hassanein, S. M. and Soliman, N. K. 2010. Effect of probiotic (Saccharomyces cerevisiae) adding to diets on intestinal microflora and performance of Hy-Line layings hens. Journal of American Science 6(11):159-169.

Katoch, S.; Ka1stha, M.; Sharma, K. S. and Kumari, M. 2003. Biological performance of chicken fed newly isolated probiotics. Indian Journal Animal Science 73:1271-1273.

Miazzo, R. D.; Peralta, M. F. and Picco, M. 2005. Perfomance productiva y calidad de la canal en broilers que recibieron levadura de cerveza (S. cerevisiae). Redvet 6:1-9. Available at: $<$ http://www. veterinaria.org/revistas/redvet>. Accessed on: April 5, 2017.

Nursoy, H.; Kaplan, O.; Oğuz, M. N.; and Yılmaz, O. 2004. Effects of varying levels of live yeast culture on yield and some parameters in laying hen diets. Indian Veterinary Journal 81:59-62.

Onifade, A. A. and Babatunde, G. M. 1996. Supplemental value of dried yeast in a high-fibre diet for broiler chicks. Animal Feed Science and Technology 62:91-96.

Önol, A. G.; Sarı, M.; Oğuz, F. M.; Gülcan, B. and Erbaş G. 2003. Sürekli sicak stresinde bulunan yumurta dönemindeki bildırcın rasyonlarına probiyotik katkısının bazı verim ve kan parametreleri üzerine etkisi. Türk Journal Animal Science 27:1397-1402.

Özsoy, B. and Yalçın, S. 2011. The effects of dietary supplementation of yeast culture on performance, blood parameters and immune system in broiler turkeys. Ankara Üniversitesi Veteriner Fakültesi Dergisi 58:117-122.

Sacakli, P.; Ergun, A.; Koksal, B. H; Ozsoy, B. and Cantekin, Z. 2013. Effects of inactivated brewer's yeast (Saccharomyces cereviciae) on egg production, serum antibody titres and cholesterol levels in laying hens. Veterinarija ir Zootechnika 61:53-60.

Shareef, A. M. and Al-Dabbagh, A. S. A. 2009. Effect of probiotic (Saccharomyces cerevisiae) on performance of broiler chicks. Iraqi Journal Veterianry Science 23(Suppl I):23-29.

Stanley, V. G.; Ojo, R.; Woldesenbet, S.; Hutchinson, D. H. and Kubena, L. 1993. The use of Saccharomyces cerevisiae to suppress the effects of aflatoxicosis in broiler chicks. Poultry Science 72(10):1867-1872.

Stone, C. W. 2007. Yeast products in the feed industry a practical guide for feed professionals. Available at: <http://www.diamondv. com/products/yc.html>. Accessed on: May 8, 2017.

Wang, H. T.; Shih, W. Y.; Chen, S. W. and Wang, S. Y. 2015. Effect of yeast with bacteriocin from rumen bacteria on laying performance, blood biochemistry, faecal microbiota and egg quality of laying hens. Journal of Animal Physiology and Animal Nutrition 99(6):1105-1115

Yalçin, S.; Özsoy, B.; Erol, H. and Yalçin, S. 2008. Yeast culture supplementation to laying hen diets containing soybean meal or sunflower seed meal and its effect on performance, egg quality traits and blood chemistry. Journal of Applied Poultry Research 17(2):229-236.

Yalçın, S.; Yalçın, S.; Çakın, K.; Eltan, Ö. and Dağaşan. L. 2010. Effects of dietary yeast autolysate (Saccharomyces cerevisiae) on performance, egg traits, egg cholesterol content, egg yolk fatty acid composition and humoral immune response of laying hens. Journal of the Science of Food and Agriculture 90(10):1695-1701.

Yalçın, S.; Uzunoğlu, K.; Duyum, H. M. and Eltan, Ö. 2012. Effects of dietary yeast autolysate (Saccharomyces cerevisiae) and black cumin seed (Nigella sativa L.) on performance, egg traits, some blood characteristics and antibody production of laying hens. Livestock Science 145(1):13-20.

Yalçın, S.; Yalçın, S.; Onbaşılar, İ.; Eser, H. and Şahin, A. 2014. Effects of dietary yeast cell wall on performance, egg quality and humoral immune response in laying hens. Ankara Üniversitesi Veteriner Fakültesi Dergisi 61:289-294.

Yalçın, S.; Yalçın, S.; Şahin, A.; Duyum, H. M.; Çalık, A. and Gümüş, H. 2015. Effects of dietary inactive yeast and live yeast on performance, egg quality traits, some blood parameters and antibody production to SRBC of laying hens. Kafkas Üniversitesi Veteriner Fakültesi Dergisi 21(3):345-350.

Yousefi, M. and Karkoodi, K. 2007. Effect of probiotic Thepax ${ }^{\circledR}$ and Saccharomyces cerevisiae supplementation on performance and egg quality of laying hens. International Journal of Poultry Science 6:52-54.

Zhong, S.; Liu, H.; Zhang, H.; Han, T.; Jia, H. and Xie, Y. 2016. Effects of Kluyveromyces marxianus isolated from Tibetan mushrooms on the plasma lipids, egg cholesterol level, egg quality and intestinal health of laying hens. Revista Brasileira de Ciência Avícola 18:261-268. 